\title{
Fuzzy Mic-Mac Analysis on Factors Affecting the Bank Queuing Systems
}

\author{
Gayathri S. \\ ICICI Bank, Bannerghatta Road, \\ Bangalore, India
}

\author{
Remica Aggarwal \\ MIT-SOER, MIT- ADT University, \\ Pune, India
}

\author{
V. K. Aggarwal \\ Recventures Education Services \\ Private limited \\ Delhi, India
}

\begin{abstract}
Present research focuses on identifying various barriers to bank queuing systems. It thereafter studies the interrelationship amongst them both by ISM methodology as well as fuzzy ISM methodology. The comparison of approaches is a novel attempt made in the field of bank queuing related research work to the best of author knowledge.
\end{abstract}

\section{Keywords}

Bank Queuing systems; Mic- Mac Analysis, Fuzzy Mic-Mac Analysis; ISM methodology

\section{INTRODUCTION}

Current globalization is characterized by intense and growing competition that does not exclude the banking industry. Managers continue to face tough challenges to the survival of their businesses. According to (Christopher M \& D., 1997), the survival of organizations depends on their ability to get closer to their clients and to understand the needs and desires of the client. For a business to succeed, it must focus on meeting the needs of customers by organizing itself to respond to them and target customers more effectively.

For many years, the subject of customer satisfaction has been on the agenda of many organizations, so satisfaction has become a crucial element and a concern for customers and organizations. Banks are among the organizations for which customer satisfaction is the key factor for success and a major source of competitiveness. Contact systems should take a close look at the theory and psychology of queues to take advantage of client participation to avoid the negative effects of delays and other psychological factors on the quality of service.

A key determinant of customer satisfaction is ease of access, which includes the location of the service facility, its hours of operation, and its minimum wait time to receive service. Waiting times are the main source of dissatisfaction. Indeed, since the customer enters a system to receive a service, and leaves the premises after being served, it is important to address the problem of queues. The lack of professional resources can be the cause or the source of dissatisfaction felt by the customers; this feeling gives them the impression of being poorly served and creates a feeling of discomfort or even insecurity at home, which can harm the quality of the service. To help decision-makers make optimal decisions, mathematical models are applied to find a solution to organizational problems and to optimize economic techniques.

The queuing theory is thus among those mathematical models that analyze and deal with the organizational difficulties faced by organizations with files to manage and organize.

Paper is organized as follows. Section 2 reviews the literature and presents the various barriers to queuing system. Section 3 presents the Fuzzy ISM methodology. Section 4 presents the managerial implications and future directions .

\section{LITERATURE REVIEW ${ }^{1-6}$}

Present section reviews the literature related to barriers associated with bank queuing systems. Further, it has been found that few research papers that are directly associated with the concept of bank queuing system , queues etc. For example, Kabamba, A.W. (2019) presents the modelling and analysis of queuing systems in banks as part of university study of Mbujimayi. Yusuf et al. 2015 base their studies on Queuing Theory and Customer Satisfaction: A Review of Performance, Trends and Application in Banking Practice. In order to collect the research papers for the review, a rigorous search was carried out using the databases such as Scopus, EBSCO , Emerald Full Text, Elsevier, Taylor and Francis etc. An advance search, within the preview of present title, was carried out using different combination of words such as, barriers to bank queueing system, bank queues , factors affecting queueing in banks, factors affecting queues . Following table presents various factors along with the description affecting the queues in bank.

\begin{tabular}{|c|c|c|}
\hline S.No. & Factors & Description \\
\hline 1. & Jockeying (Jo) & $\begin{array}{c}\text { When the customers enter one } \\
\text { queue and after sometime he/she } \\
\text { switches to a different queue in an } \\
\text { effort to reduce the waiting time }\end{array}$ \\
\hline 2. & Reneging (Re); & $\begin{array}{c}\text { The customer enters the line but } \\
\text { later it decides to leave the queue } \\
\text { before being served }\end{array}$ \\
\hline 3. & $\begin{array}{c}\text { Number of } \\
\text { service stations } \\
\text { (NSS) i.e. high } \\
\text { number of } \\
\text { service stations } \\
\text { (HNSS) }\end{array}$ & $\begin{array}{c}\text { The number of service stations is } \\
\text { always a factor of concern, } \\
\text { optimum number of service } \\
\text { stations is always desirable. }\end{array}$ \\
\hline 4. & $\begin{array}{c}\text { Low Number } \\
\text { of service } \\
\text { stations } \\
\text { (LNSS) }\end{array}$ & $\begin{array}{c}\text { The bank can have high number } \\
\text { of service stations or may have } \\
\text { low number of service stations } \\
\text { depending upon nature of arrival } \\
\text { of customers at the service } \\
\text { counters in the bank. }\end{array}$ \\
\hline 5. & $\begin{array}{c}\text { Throughput } \\
\text { time of service } \\
\text { provider } \\
\text { (TTSP) }\end{array}$ & $\begin{array}{c}\text { During calculation of service rate } \\
\text { standard time is taken but in actual } \\
\text { practice it will always mismatch } \\
\text { and due to fatigue, service time } \\
\text { increases. }\end{array}$ \\
\hline 6. & $\begin{array}{c}\text { Illiteracy of } \\
\text { Information filled by the }\end{array}$ \\
\hline
\end{tabular}




\begin{tabular}{|c|c|c|}
\hline & $\begin{array}{l}\text { customers } \\
\text { (IoC) }\end{array}$ & $\begin{array}{l}\text { customers are sometimes wrong or } \\
\text { incomplete. }\end{array}$ \\
\hline 7 & $\begin{array}{l}\text { Technical } \\
\text { errors (TE) }\end{array}$ & $\begin{array}{l}\text { Some of the factors such as } \\
\text { electricity cut-off or server } \\
\text { downtime to error in networking } \\
\text { connections affect servicing. }\end{array}$ \\
\hline 8 & $\begin{array}{l}\text { Wrong forecast } \\
\text { (WF) }\end{array}$ & $\begin{array}{l}\text { Forecasting and preparing for the } \\
\text { forecasted assumption is a good } \\
\text { managerial decisions but wrong } \\
\text { assumption will misalign the } \\
\text { service rate and customer arrival } \\
\text { rate. }\end{array}$ \\
\hline 9 & $\begin{array}{l}\text { Seasonal and } \\
\text { off-seasonal } \\
\text { factors (S-oSF) }\end{array}$ & $\begin{array}{l}\text { Some of the factors like festivals } \\
\text { and salary time starting of the } \\
\text { month results into increase of } \\
\text { customer arrival rate which leads } \\
\text { to increase in the length of queue. }\end{array}$ \\
\hline 10 & Balking (Ba) & $\begin{array}{l}\text { The customers on watching the } \\
\text { long length of queue decides not } \\
\text { to enter the long waiting line. }\end{array}$ \\
\hline 11 & $\begin{array}{l}\text { Waiting time * } \\
\text { (WT) }\end{array}$ & $\begin{array}{l}\text { Waiting times are the main source } \\
\text { of dissatisfaction. Indeed, since } \\
\text { the customer enters a system to } \\
\text { receive a service, and leaves the } \\
\text { premises after being served, it is } \\
\text { important to address the problem } \\
\text { of queues. }\end{array}$ \\
\hline 12 & $\begin{array}{c}\text { Quality of } \\
\text { service * (QS) }\end{array}$ & $\begin{array}{l}\text { A key determinant of customer } \\
\text { satisfaction is ease of access, } \\
\text { which includes the location of the } \\
\text { service facility, its hours of } \\
\text { operation, and its minimum wait } \\
\text { time to receive service. }\end{array}$ \\
\hline 13 & $\begin{array}{l}\text { Lack of } \\
\text { professional } \\
\text { resources* } \\
(\text { LPR) }\end{array}$ & $\begin{array}{l}\text { The lack of professional resources } \\
\text { can be the cause or the source of } \\
\text { dissatisfaction felt by the } \\
\text { customers. This creates a feeling } \\
\text { of discomfort or even insecurity at } \\
\text { home, which can harm the quality } \\
\text { of the service. }\end{array}$ \\
\hline 14 & $\begin{array}{c}\text { Personal } \\
\text { factors on part } \\
\text { of employees } \\
\text { (PFE) }\end{array}$ & $\begin{array}{c}\text { Factors such as fatigue , sickness } \\
\text { of employee etc. may delay the } \\
\text { service and result in more waiting } \\
\text { time }\end{array}$ \\
\hline
\end{tabular}

*Mitewu Kabababa, Alex 2019. Modelling and Analysis of Queuing Systems in Banks . https://mpra.ub.unimuenchen.de/92579/

\section{INTERPRETIVE STRUCTURAL MODELLING METHODOLOGY 4.1 ISM based Mic-Mac analysis model for the non- fuzzy data of bank queuing system}

Proposed by Warfield in 1974, ISM methodology is a technique for establishing inter-relationships amongst the criteria of interest. This is done via a number of steps. The process begins with the identification of relevant elements and thereafter establishing contextual relationship amongst them . After that the structural self - interaction matrix is created using the VAXO concept which is then followed by the creation of initial reachability matrix . Final reachability matrix is then created after correcting the initial reachability matrix for any possibility of transitivity. From the reachability matrix, the reachability set and antecedent set for each criterion is found. Then the intersection of these sets is derived for all elements. The element for which the reachability and intersection sets are the same is the top-level element. Then the reachability matrix is converted into the canonical matrix format by arranging the elements according to their levels. Based on the relative driving power and dependence power, factors are classified in various categories like autonomous, dependent, driver and linkage. Finally, a diagraph is constructed from the canonical matrix .

\subsubsection{Structural Self Interaction matrix}

In this section we will develop the ISM model for the various barriers faced by bank queuing models. As mentioned in section 2, 12 important barriers have been identified viz. Jockeying (Jo) ; Reneging (Re); high number of service stations (HNSS) ; low number of service stations (LNSS) ; Throughput time of service provider (TTSP) ; Illiteracy of customers (IoC) ; Technical errors (TE); Wrong forecast (WF) ; Seasonal and off-seasonal factors (S-oSF) ; Balking (Ba) ; Waiting time* (WT) ; Quality of service* (QS) and Lack of professional resources* (LPR) and personal factors on part of employees (PFE) have been studied for exploring the possible inter-relationships using ISM methodology .

\section{DEVELOPMENT OF ISM AND FUZZY ISM MODEL CASE EXAMPLE}

\subsection{ISM MODEL}

Challenges described in the above section are being further studied for the possible inter-relationships amongst them. These are Limited or Lack of Knowledge and awareness (LKA); Attitude of higher management towards BMW management and house- keeping staff (AHM); Lack of training and education (LTE); Poor practice of recapping the needles (PPRN); Improper Employee Time \& Inefficiency of the Biomedical waste handling process (IETIE); Patient Safety risk (PSR) ; Employee Safety risk (ES); Problematic waste segregation process (PWSP) ; problematic handling of overall wet waste (PHWW); Lack of apathy(LoA).

Explanation : Jockeying may leads to reneging as the customer even after changing the queue in order to avoid wastage of time still did not receive the service and hence leave the counter. The more the number of service stations, the more the chances of jockeying as there is a possibility that the customer may find some other counter free for service. In the similar manner less number of service centers may lead to reneging . Reneging may promote to have high number of service stations. Bank may allow less number of counters to discourage jockeying. Low number of service stations may promote to increase the number of service stations. High quality and effective service on part of employee mat result in less number of service stations . Similarly, weak or inefficient service may result in high number of service stations. illiteracy of customers affect almost all the barriers as the bank may increase its number of employees to give better service to customers as they are not that educated enough. Technical errors may result in high number of service stations and also jockeying and finally reneging. 


\subsubsection{Construction of Structural self-interaction Matrix (SSIM)}

This matrix gives the pair-wise relationship between two variables i.e. I and $j$ based on VAXO. SSIM has been presented below in Fig 1.

\subsubsection{Construction of Initial Reachability Matrix and final reachability matrix}

The SSIM has been converted in to a binary matrix called the initial reachability matrix shown in fig. 2 by substituting $\mathrm{V}, \mathrm{A}$, $\mathrm{X}, \mathrm{O}$ by 1 or 0 as per the case. After incorporating the transitivity, the final reachability matrix is shown below in the Fig 3.

\subsubsection{Level Partition}

From the final reachability matrix, reachability and final antecedent set for each factor are found. The elements for which the reachability and intersection sets are same are the top-level element in the ISM hierarchy. After the identification of top level element, it is separated out from the other elements and the process continues for next level of elements. Reachability set, antecedent set, intersection set along with different level for elements have been shown below in table 4.1.3.1- Table 4.1.3.10.

\subsection{Fuzzy ISM methodology}

\subsubsection{Formation of ISM based fuzzy Mic-Mac analysis model}

With the help of key enablers this analysis is done keeping in mind that the relationship amongst enablers would always be equal. However in reality, this may not be true. Some relation may be strong, especially strong and better. To rise above this problem of ISM, fuzzy MICMAC analysis is moved away as per following steps

\subsubsection{Binary direct relationship matrix}

From the direct examination relationship between the enablers in the ISM, a binary direct reachability matrix (BDRM) is obtained and the diagonal entries are converted to zero. It has been observed that in the traditional Mic-Mac analysis the relationship is the only binary type, but in this paper fuzzy set theory (FST) is applied to enhance the responsiveness of MicMac analysis. The BDRM is shown in Table.7. To convert from traditional Mic-Mac analysis to fuzzy Mic-Mac, a supplementary contribution of option of communication among the enablers is required. The supplementary contribution can be defined by qualitative consideration on 0 1 scale as shown in Table.8.

\subsubsection{Fuzzy direct reachability matrix \\ 4.2.4 Fuzzy Mic-Mac Stabilized Matrix}

After the formation of fuzzy direct relationship matrix (FDRM) as shown in Table VI to find the relationship between MCEs, take FDRM as an initial table and repeat the multiplication of matrix until the hierarchies of the driving and dependence power becomes constant. Fuzzy matrix multiplication is based on Boolean matrix multiplication (Kandasamy et al., 2007). According, to fuzzy set theory, when two fuzzy matrices are multiplied the product matrix is also fuzzy matrix.
Table 4.1.3.1: Iteration I

\begin{tabular}{|c|c|c|c|c|}
\hline $\begin{array}{c}\text { S.No } \\
\text {. }\end{array}$ & $\begin{array}{c}\text { Reachability } \\
\text { set }\end{array}$ & Antecedent set & $\begin{array}{c}\text { Intersectio } \\
\text { n set }\end{array}$ & $\begin{array}{c}\text { Lev } \\
\text { el }\end{array}$ \\
\hline 1 & 10 & $\begin{array}{r}1,2,3,4,5,6,7,8,9 \\
10,11,12,13,14\end{array}$ & 10 & \multirow{10}{*}{ I } \\
\hline 2 & $1,2,3,10$ & $\begin{array}{c}1,2,3,4,5,6,7,8,9 \\
11,12,13,14\end{array}$ & $1,2,3$ & \\
\hline 3 & $1,2,3,4,10$ & $\begin{array}{c}1,3,4,5,6,7,8,9 \\
11,12,13,14\end{array}$ & $1,3,4$ & \\
\hline 4 & $1,2,3,4,5,10$ & $\begin{array}{c}5,6,7,8,9,11 \\
12,13,14\end{array}$ & 5 & \\
\hline 5 & $\begin{array}{c}1,2,3,4,5,6, \\
10\end{array}$ & $\begin{array}{c}6,7,8,9,11,12,13 \\
14\end{array}$ & 6 & \\
\hline 6 & $\begin{array}{l}1,2,3,4,5,6, \\
10,12,13,14\end{array}$ & $\begin{array}{c}7,8,9,11,12,13 \\
14\end{array}$ & $12,13,14$ & \\
\hline 7 & $\begin{array}{c}1,2,3,4,5,6 \\
10,11,12,13 \\
14\end{array}$ & $7,8,9,11,13,14$ & $11,13,14$ & \\
\hline 8 & $\begin{array}{c}1,2,3,4,5,6,7 \\
10,11,12,13 \\
14\end{array}$ & $7,8,9,13,14$ & $7,13,14$ & \\
\hline 9 & $\begin{array}{c}1,2,3,4,5,6,7 \\
8,10,11,12 \\
13,14\end{array}$ & $8,9,13,14$ & $8,13,14$ & \\
\hline 10 & $\begin{array}{c}1,2,3,4,5,6,7 \\
8,9,10,11 \\
12,13,14\end{array}$ & 9 & 9 & \\
\hline
\end{tabular}

Table 4.1.3.2: Iteration II

\begin{tabular}{|c|c|c|c|c|}
\hline $\begin{array}{l}\text { S. } \\
\text { No }\end{array}$ & $\begin{array}{c}\text { Reachability } \\
\text { set }\end{array}$ & Antecedent set & $\begin{array}{c}\text { Intersectio } \\
\text { n set }\end{array}$ & $\begin{array}{c}\text { Lev } \\
\text { el }\end{array}$ \\
\hline 2 & $1,2,3$ & $\begin{array}{c}1,2,3,4,5,6,7,8 \\
9,11,12,13,14\end{array}$ & $1,2,3$ & \multirow{7}{*}{ II } \\
\hline 3 & $1,2,3,4,10$ & $\begin{array}{c}1,3,4,5,6,7,8,9 \\
11,12,13,14\end{array}$ & $1,3,4$ & \\
\hline 4 & $1,2,3,4,5,10$ & $\begin{array}{c}5,6,7,8,9,11 \\
12,13,14\end{array}$ & 5 & \\
\hline 5 & $\begin{array}{c}1,2,3,4,5,6 \\
10\end{array}$ & $\begin{array}{c}6,7,8,9,11,12,1 \\
3,14\end{array}$ & 6 & \\
\hline 6 & $\begin{array}{c}1,2,3,4,5,6,10 \\
12,13,14\end{array}$ & $\begin{array}{c}7,8,9,11,12,13 \\
14\end{array}$ & $12,13,14$ & \\
\hline 7 & $\begin{array}{c}1,2,3,4,5,6 \\
10,11,12,13 \\
14\end{array}$ & $7,8,9,11,13,14$ & $11,13,14$ & \\
\hline 8 & $\begin{array}{c}1,2,3,4,5,6,7 \\
10\end{array}$ & $7,8,9,13,14$ & $7,13,14$ & \\
\hline
\end{tabular}




\begin{tabular}{|c|c|c|c|}
\hline & $11,12,13,14$ & & \\
\hline 9 & $\begin{array}{c}1,2,3,4,5,6,7,8 \\
10,11,12,13 \\
14\end{array}$ & $8,9,13,14$ & $8,13,14$ \\
\hline 10 & $\begin{array}{c}1,2,3,4,5,6,7,8 \\
9,10,11,12 \\
13,14\end{array}$ & 9 & 9 \\
\hline
\end{tabular}

Table 4.1.3.3: Iteration III

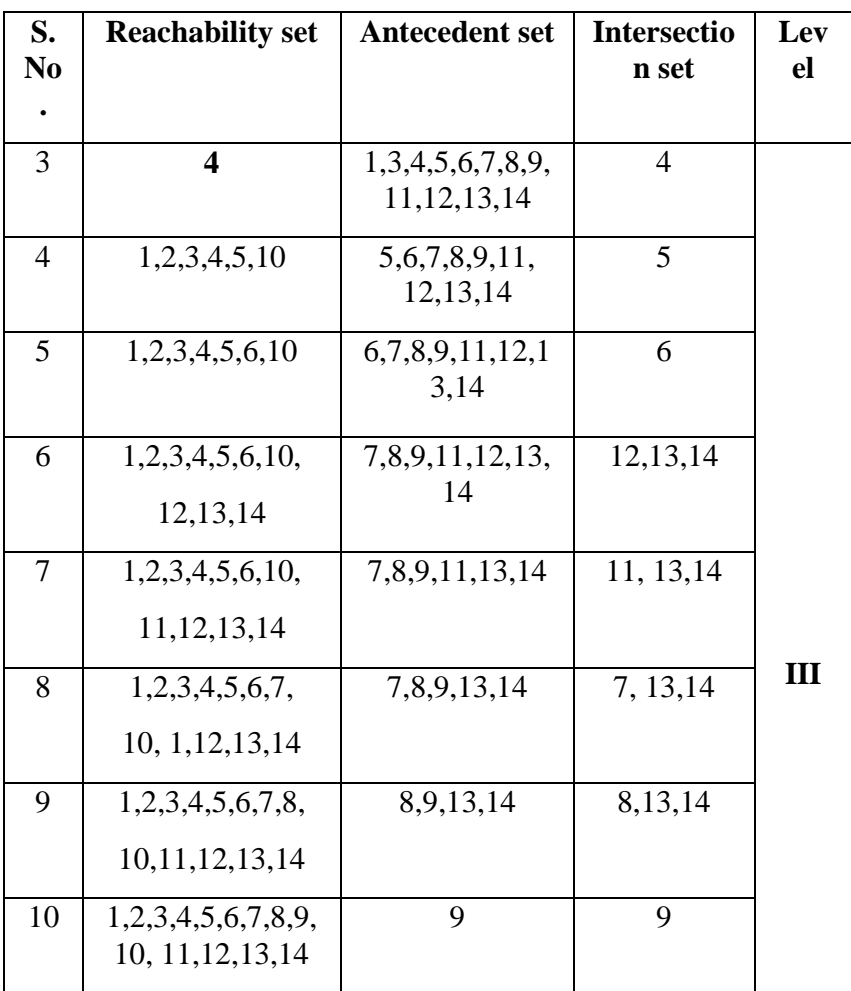

Table 4.1.3.4: Iteration IV

\begin{tabular}{|c|c|c|c|c|}
\hline $\begin{array}{l}\text { S. } \\
\text { No }\end{array}$ & Reachability set & Antecedent set & $\begin{array}{c}\text { Intersectio } \\
\text { n set }\end{array}$ & $\begin{array}{c}\text { Lev } \\
\text { el }\end{array}$ \\
\hline 4 & 5 & $\begin{array}{c}5,6,7,8,9,11,12, \\
13,14\end{array}$ & 5 & \multirow{7}{*}{ IV } \\
\hline 5 & $1,2,3,4,5,6,10$ & $\begin{array}{c}6,7,8,9,11,12,1 \\
3,14\end{array}$ & 6 & \\
\hline 6 & $\begin{array}{c}1,2,3,4,5,6,10 \\
12,13,14\end{array}$ & $\begin{array}{c}7,8,9,11,12,13 \\
14\end{array}$ & $12,13,14$ & \\
\hline 7 & $\begin{array}{c}1,2,3,4,5,6,10 \\
11,12,13,14\end{array}$ & $7,8,9,11,13,14$ & $11,13,14$ & \\
\hline 8 & $\begin{array}{c}1,2,3,4,5,6,7,10 \\
11,12,13,14\end{array}$ & $7,8,9,13,14$ & $7,13,14$ & \\
\hline 9 & $\begin{array}{l}1,2,3,4,5,6,7,8, \\
10,11,12,13,14\end{array}$ & $8,9,13,14$ & $8,13,14$ & \\
\hline 10 & $\begin{array}{c}1,2,3,4,5,6,7,8,9 \\
10,11,12,13,14\end{array}$ & 9 & 9 & \\
\hline
\end{tabular}

Table 4.1.3.5: Iteration $\mathrm{V}$

\begin{tabular}{|c|c|c|c|c|}
\hline $\begin{array}{l}\text { S. } \\
\text { No }\end{array}$ & Reachability set & Antecedent set & $\begin{array}{c}\text { Intersectio } \\
\text { n set }\end{array}$ & $\begin{array}{c}\text { Lev } \\
\text { el }\end{array}$ \\
\hline 5 & 6 & $\begin{array}{c}6,7,8,9,11,12,1 \\
3,14\end{array}$ & 6 & \multirow{6}{*}{$\mathbf{V}$} \\
\hline 6 & $\begin{array}{c}1,2,3,4,5,6,10 \\
12,13,14\end{array}$ & $\begin{array}{c}7,8,9,11,12,13 \\
14\end{array}$ & $12,13,14$ & \\
\hline 7 & $\begin{array}{c}1,2,3,4,5,6,10 \\
11,12,13,14\end{array}$ & $7,8,9,11,13,14$ & $11,13,14$ & \\
\hline 8 & $\begin{array}{c}1,2,3,4,5,6,7,10 \\
11,12,13,14\end{array}$ & $7,8,9,13,14$ & $7,13,14$ & \\
\hline 9 & $\begin{array}{l}1,2,3,4,5,6,7,8 \\
10,11,12,13,14\end{array}$ & $8,9,13,14$ & $8,13,14$ & \\
\hline 10 & $\begin{array}{c}1,2,3,4,5,6,7,8,9 \\
10,11,12,13,14\end{array}$ & 9 & 9 & \\
\hline
\end{tabular}

Table 4.1.3.6: Iteration VI

\begin{tabular}{|c|c|c|c|c|}
\hline $\begin{array}{l}\text { S. } \\
\text { No }\end{array}$ & Reachability set & Antecedent set & $\begin{array}{c}\text { Intersectio } \\
\text { n set }\end{array}$ & $\begin{array}{c}\text { Lev } \\
\text { el }\end{array}$ \\
\hline 6 & $12,13,14$ & $\begin{array}{c}7,8,9,11,12,13 \\
14\end{array}$ & $12,13,14$ & \multirow{5}{*}{ VI } \\
\hline 7 & $\begin{array}{c}1,2,3,4,5,6,10,11 \\
12,13,14\end{array}$ & $7,8,9,11,13,14$ & $11,13,14$ & \\
\hline 8 & $\begin{array}{c}1,2,3,4,5,6,7,10 \\
11,12,13,14\end{array}$ & $7,8,9,13,14$ & $7,13,14$ & \\
\hline 9 & $\begin{array}{c}1,2,3,4,5,6,7,8,10 \\
, 11,12,13,14\end{array}$ & $8,9,13,14$ & $8,13,14$ & \\
\hline 10 & $\begin{array}{c}1,2,3,4,5,6,7,8,9 \\
10,11,12,13,14\end{array}$ & 9 & 9 & \\
\hline
\end{tabular}

Table 4.1.3.7: Iteration VII

\begin{tabular}{|c|c|c|c|c|}
\hline $\begin{array}{l}\text { S. } \\
\text { No }\end{array}$ & Reachability set & Antecedent set & $\begin{array}{c}\text { Intersectio } \\
\text { n set }\end{array}$ & $\begin{array}{c}\text { Lev } \\
\text { el }\end{array}$ \\
\hline 7 & 11 & $7,8,9,11$ & 11 & \multirow{4}{*}{ VII } \\
\hline 8 & $\begin{array}{c}1,2,3,4,5,6,7,10 \\
11,12,13,14\end{array}$ & $7,8,9,13,14$ & $7,13,14$ & \\
\hline 9 & $\begin{array}{c}1,2,3,4,5,6,7,8, \\
10,11,12,13,14\end{array}$ & $8,9,13,14$ & $8,13,14$ & \\
\hline 10 & $\begin{array}{c}1,2,3,4,5,6,7,8,9 \\
10,11,12,13,14\end{array}$ & 9 & 9 & \\
\hline
\end{tabular}


Table 4.1.3.8: Iteration VIII

\begin{tabular}{|c|c|c|c|c|}
\hline $\begin{array}{c}\text { S.No } \\
\cdot\end{array}$ & Reachability set & $\begin{array}{c}\text { Antecedent } \\
\text { set }\end{array}$ & $\begin{array}{c}\text { Intersectio } \\
\text { n set }\end{array}$ & $\begin{array}{c}\text { Leve } \\
\mathbf{l}\end{array}$ \\
\hline 8 & $\mathbf{7}$ & $7,8,9$ & $\mathbf{7}$ & \\
\hline 9 & $\begin{array}{c}1,2,3,4,5,6,7,8, \\
10,11,12,13,14\end{array}$ & $8,9,13,14$ & $8,13,14$ & \\
\cline { 1 - 4 } 10 & $\begin{array}{c}1,2,3,4,5,6,7,8,9, \\
10,11,12,13,14\end{array}$ & 9 & 9 & VIII \\
& & & & \\
\hline
\end{tabular}

Table 4.1.3.9: Iteration IX

\begin{tabular}{|c|c|c|c|c|}
\hline $\begin{array}{c}\text { S. } \\
\text { No } \\
\cdot\end{array}$ & Reachability set & Antecedent set & $\begin{array}{c}\text { Intersectio } \\
\text { n set }\end{array}$ & $\begin{array}{c}\text { Leve } \\
\text { I }\end{array}$ \\
\hline 9 & $\mathbf{8}$ & 8,9 & 8 & \multirow{2}{*}{ IX } \\
\hline 10 & $\begin{array}{c}1,2,3,4,5,6,7,8,9, \\
10,11,12,13,14\end{array}$ & 9 & 9 & \\
\hline
\end{tabular}

Table 4.1.3.10 : Iteration $X$

\begin{tabular}{|c|c|c|c|c|c|}
\hline $\begin{array}{c}\text { S. } \\
\text { No }\end{array}$ & $\begin{array}{c}\text { Reachability } \\
\text { set }\end{array}$ & $\begin{array}{c}\text { Antecedent } \\
\text { set }\end{array}$ & $\begin{array}{c}\text { Intersection } \\
\text { set }\end{array}$ & Iteration \\
\hline 10 & $\mathbf{9}$ & 9 & 9 & $\mathbf{X}$ \\
\hline
\end{tabular}

\begin{tabular}{|c|c|c|c|c|c|c|c|c|c|c|c|c|c|c|c|}
\hline & & 1 & 2 & 3 & 4 & 5 & 6 & 7 & 8 & 9 & 10 & 11 & 12 & 13 & 14 \\
\hline & & Jo & $\operatorname{Re}$ & $\begin{array}{c}\text { HNS } \\
\mathrm{S}\end{array}$ & $\begin{array}{c}\text { LNS } \\
\text { S }\end{array}$ & $\begin{array}{c}\text { TTS } \\
\mathbf{P}\end{array}$ & IoC & TE & WF & $\begin{array}{c}\text { S- } \\
\text { OSF }\end{array}$ & $\mathbf{B a}$ & WT & QS & LPR & PFE \\
\hline 1 & Jo & & V & $\mathrm{A}$ & V & A & $\mathrm{A}$ & $\mathrm{A}$ & $\mathrm{A}$ & $\mathrm{A}$ & $\mathrm{V}$ & $\mathrm{A}$ & $\mathrm{A}$ & $\mathrm{A}$ & $\mathrm{A}$ \\
\hline 2 & $\operatorname{Re}$ & & & V & A & A & A & A & A & A & V & A & A & A & A \\
\hline 3 & HNSS & & & & A & A & A & A & A & A & V & A & A & A & A \\
\hline 4 & LNSS & & & & & A & A & A & A & A & $\mathrm{V}$ & A & A & A & A \\
\hline 5 & TTSP & & & & & & A & A & A & A & $\mathrm{V}$ & A & A & A & A \\
\hline 6 & IoC & & & & & & & A & A & A & $\mathrm{V}$ & A & A & A & A \\
\hline 7 & $\mathrm{TE}$ & & & & & & & & A & A & $\mathrm{V}$ & V & $\mathrm{V}$ & A & A \\
\hline 8 & WF & & & & & & & & & A & V & V & V & A & A \\
\hline 9 & S-oSF & & & & & & & & & & $\mathrm{V}$ & V & $\mathrm{V}$ & $\mathrm{V}$ & V \\
\hline 10 & $\mathrm{Ba}$ & & & & & & & & & & & A & A & A & A \\
\hline 11 & WT & & & & & & & & & & & & $\mathrm{V}$ & $\mathrm{V}$ & $\mathrm{V}$ \\
\hline 12 & QS & & & & & & & & & & & & & $\mathrm{V}$ & $\mathrm{V}$ \\
\hline 13 & LPR & & & & & & & & & & & & & & $X$ \\
\hline 14 & PFE & & & & & & & & & & & & & & \\
\hline
\end{tabular}

Fig 1: SSIM matrix for pair wise relationship amongst barriers

\begin{tabular}{|c|c|c|c|c|c|c|c|c|c|c|c|c|c|c|c|}
\hline & & $\mathbf{1}$ & $\mathbf{2}$ & $\mathbf{3}$ & $\mathbf{4}$ & $\mathbf{5}$ & $\mathbf{6}$ & $\mathbf{7}$ & $\mathbf{8}$ & $\mathbf{9}$ & $\mathbf{1 0}$ & $\mathbf{1 1}$ & 12 & 13 & 14 \\
\hline & & $\mathbf{J o}$ & $\mathbf{R e}$ & $\mathbf{H N S}$ & $\mathbf{L N S S}$ & $\mathbf{T T S P}$ & $\mathbf{I O C}$ & $\mathbf{T E}$ & $\mathbf{W F}$ & $\begin{array}{c}\text { S- } \\
\mathbf{O S F}\end{array}$ & $\mathbf{B a}$ & WT & QS & LPR & PFE \\
\hline 1 & Jo & 1 & 1 & 0 & 1 & 0 & 0 & 0 & 0 & 0 & 1 & 0 & 0 & 0 & 0 \\
\hline 2 & Re & 0 & 1 & 1 & 0 & 0 & 0 & 0 & 0 & 0 & 1 & 0 & 0 & 0 & 0 \\
\hline 3 & HNSS & 1 & 0 & 1 & 0 & 0 & 0 & 0 & 0 & 0 & 1 & 0 & 0 & 0 & 0 \\
\hline 4 & LNSS & 0 & 1 & 1 & 1 & 0 & 0 & 0 & 0 & 0 & 1 & 0 & 0 & 0 & 0 \\
\hline 5 & TTSP & 1 & 1 & 1 & 1 & 1 & 0 & 0 & 0 & 0 & 1 & 0 & 0 & 0 & 0 \\
\hline 6 & IoC & 1 & 1 & 1 & 1 & 1 & 1 & 0 & 0 & 0 & 1 & 0 & 0 & 0 & 0 \\
\hline 7 & TE & 1 & 1 & 1 & 1 & 1 & 1 & 1 & 0 & 0 & 1 & 1 & 1 & 0 & 0 \\
\hline 8 & WF & 1 & 1 & 1 & 1 & 1 & 1 & 1 & 1 & 0 & 1 & 1 & 1 & 0 & 0 \\
\hline 9 & S-oSF & 1 & 1 & 1 & 1 & 1 & 1 & 1 & 1 & 1 & 1 & 1 & 1 & 1 & 1 \\
\hline 10 & Ba & 0 & 0 & 0 & 0 & 0 & 0 & 0 & 0 & 0 & 1 & 0 & 0 & 0 & 0 \\
\hline
\end{tabular}




\begin{tabular}{|c|c|c|c|c|c|c|c|c|c|c|c|c|c|c|c|}
\hline 11 & WT & 1 & 1 & 1 & 1 & 1 & 1 & 0 & 0 & 0 & 1 & 1 & 1 & 1 & 1 \\
\hline 12 & QS & 1 & 1 & 1 & 1 & 1 & 1 & 0 & 0 & 0 & 1 & 0 & 1 & 1 & 1 \\
\hline 13 & LPR & 1 & 1 & 1 & 1 & 1 & 1 & 1 & 1 & 0 & 1 & 0 & 0 & 1 & 1 \\
\hline 14 & PFE & 1 & 1 & 1 & 1 & 1 & 1 & 1 & 1 & 0 & 1 & 0 & 0 & 1 & 1 \\
\hline
\end{tabular}

Fig 2: Initial reachability matrix

\begin{tabular}{|c|c|c|c|c|c|c|c|c|c|c|c|c|c|c|c|c|}
\hline & & 1 & 2 & 3 & 4 & 5 & 6 & 7 & 8 & 9 & 10 & 11 & 12 & 13 & 14 & D.P \\
\hline & & Jo & $\mathbf{R e}$ & $\begin{array}{c}\text { HNS } \\
\text { S }\end{array}$ & $\begin{array}{c}\text { LNS } \\
\text { S }\end{array}$ & $\begin{array}{c}\text { TTS } \\
\text { P }\end{array}$ & IoC & TE & WF & $\begin{array}{c}\text { S- } \\
\text { oSF }\end{array}$ & $\mathbf{B a}$ & WT & $\overline{Q S}$ & LPR & PFE & \\
\hline 1 & Jo & 1 & 1 & 1 & 1 & 0 & 0 & 0 & 0 & 0 & 1 & 0 & 0 & 0 & 0 & 5 \\
\hline 2 & $\mathrm{Re}$ & 1 & 1 & 1 & 0 & 0 & 0 & 0 & 0 & 0 & 1 & 0 & 0 & 0 & 0 & 4 \\
\hline 3 & HNSS & 1 & 1 & 1 & 1 & 0 & 0 & 0 & 0 & 0 & 1 & 0 & 0 & 0 & 0 & 5 \\
\hline 4 & LNSS & 1 & 1 & 1 & 1 & 0 & 0 & 0 & 0 & 0 & 1 & 0 & 0 & 0 & 0 & 5 \\
\hline 5 & TTSP & 1 & 1 & 1 & 1 & 1 & 0 & 0 & 0 & 0 & 1 & 0 & 0 & 0 & 0 & 6 \\
\hline 6 & IoC & 1 & 1 & 1 & 1 & 1 & 1 & 0 & 0 & 0 & 1 & 0 & 0 & 0 & 0 & 7 \\
\hline 7 & TE & 1 & 1 & 1 & 1 & 1 & 1 & 1 & 0 & 0 & 1 & 1 & 1 & 1 & 1 & 12 \\
\hline 8 & $\overline{W F}$ & 1 & 1 & 1 & 1 & 1 & 1 & 1 & 1 & 0 & 1 & 1 & 1 & 1 & 1 & 13 \\
\hline 9 & S-oSF & 1 & 1 & 1 & 1 & 1 & 1 & 1 & 1 & 1 & 1 & 1 & 1 & 1 & 1 & 14 \\
\hline 10 & $\mathrm{Ba}$ & 0 & 0 & 0 & 0 & 0 & 0 & 0 & 0 & 0 & 1 & 0 & 0 & 0 & 0 & 1 \\
\hline 11 & WT & 1 & 1 & 1 & 1 & 1 & 1 & 0 & 0 & 0 & 1 & 1 & 1 & 1 & 1 & 11 \\
\hline 12 & QS & 1 & 1 & 1 & 1 & 1 & 1 & 0 & 0 & 0 & 1 & 0 & 1 & 1 & 1 & 10 \\
\hline 13 & LPR & 1 & 1 & 1 & 1 & 1 & 1 & 1 & 1 & 0 & 1 & 1 & 1 & 1 & 1 & 13 \\
\hline \multirow[t]{2}{*}{14} & PFE & 1 & 1 & 1 & 1 & 1 & 1 & 1 & 1 & 0 & 1 & 1 & 1 & 1 & 1 & 12 \\
\hline & De.P & 13 & 13 & 13 & 12 & 9 & 8 & 5 & 4 & 1 & 14 & 6 & 7 & 7 & 7 & \\
\hline
\end{tabular}

Fig 3 : Final reachability matrix

D.P : Driving power ; De.P : dependence power

\begin{tabular}{|c|c|c|c|c|c|c|c|c|c|c|c|c|c|c|c|}
\hline & & $\mathbf{1}$ & $\mathbf{2}$ & $\mathbf{3}$ & $\mathbf{4}$ & $\mathbf{5}$ & $\mathbf{6}$ & $\mathbf{7}$ & $\mathbf{8}$ & $\mathbf{9}$ & $\mathbf{1 0}$ & $\mathbf{1 1}$ & 12 & 13 & 14 \\
\hline & & $\mathbf{J o}$ & $\mathbf{R e}$ & $\mathbf{H N S S}$ & $\mathbf{L N S S}$ & $\mathbf{T T S}$ & $\mathbf{I 0 C}$ & $\mathbf{T E}$ & $\mathbf{W F}$ & $\mathbf{S - 0 S F}$ & $\mathbf{B a}$ & $\mathbf{W T}$ & $\mathbf{Q S}$ & LPR & $\mathbf{P F E}$ \\
\hline 1 & Jo & 0 & 1 & 1 & 1 & 0 & 0 & 0 & 0 & 0 & 1 & 0 & 0 & 0 & 0 \\
\hline 2 & Re & 1 & 0 & 1 & 0 & 0 & 0 & 0 & 0 & 0 & 1 & 0 & 0 & 0 & 0 \\
\hline 3 & HNSS & 1 & 1 & 0 & 1 & 0 & 0 & 0 & 0 & 0 & 1 & 0 & 0 & 0 & 0 \\
\hline 4 & LNSS & 1 & 1 & 1 & 0 & 0 & 0 & 0 & 0 & 0 & 1 & 0 & 0 & 0 & 0 \\
\hline 5 & TTSP & 1 & 1 & 1 & 1 & 0 & 0 & 0 & 0 & 0 & 1 & 0 & 0 & 0 & 0 \\
\hline 6 & IoC & 1 & 1 & 1 & 1 & 1 & 0 & 0 & 0 & 0 & 1 & 0 & 0 & 0 & 0 \\
\hline 7 & TE & 1 & 1 & 1 & 1 & 1 & 1 & 0 & 0 & 0 & 1 & 1 & 1 & 1 & 1 \\
\hline 8 & WF & 1 & 1 & 1 & 1 & 1 & 1 & 1 & 0 & 0 & 1 & 1 & 1 & 1 & 1 \\
\hline 9 & S-OSF & 1 & 1 & 1 & 1 & 1 & 1 & 1 & 1 & 0 & 1 & 1 & 1 & 1 & 1 \\
\hline 10 & Ba & 0 & 0 & 0 & 0 & 0 & 0 & 0 & 0 & 0 & 0 & 0 & 0 & 0 & 0 \\
\hline 11 & WT & 1 & 1 & 1 & 1 & 1 & 1 & 0 & 0 & 0 & 1 & 0 & 1 & 1 & 1 \\
\hline 12 & QS & 1 & 1 & 1 & 1 & 1 & 1 & 0 & 0 & 0 & 1 & 0 & 0 & 1 & 1 \\
\hline 13 & LPR & 1 & 1 & 1 & 1 & 1 & 1 & 1 & 1 & 0 & 1 & 1 & 1 & 0 & 1 \\
\hline 14 & PFE & 1 & 1 & 1 & 1 & 1 & 1 & 1 & 1 & 0 & 1 & 1 & 1 & 1 & 0 \\
\hline
\end{tabular}

Fig 4. Binary direct reachability matrix 


\begin{tabular}{|c|c|c|c|c|c|c|c|}
\hline Possibility of reachability & No & Very low & Low & Medium & High & Very high & Complete \\
\hline Value & 0 & 0.1 & 0.3 & 0.5 & 0.7 & 0.9 & 1 \\
\hline
\end{tabular}

Fig 5. Possibility of numerical values of reachability

\begin{tabular}{|c|c|c|c|c|c|c|c|c|c|c|c|c|c|c|c|}
\hline & & 1 & 2 & 3 & 4 & 5 & 6 & 7 & 8 & 9 & 10 & 11 & 12 & 13 & 14 \\
\hline & & Jo & $\mathbf{R e}$ & $\begin{array}{c}\text { HNS } \\
\text { S }\end{array}$ & $\begin{array}{c}\text { LNS } \\
\text { S }\end{array}$ & $\begin{array}{c}\text { TTS } \\
\text { P }\end{array}$ & IoC & TE & WF & $\begin{array}{c}\text { S- } \\
\text { oSF }\end{array}$ & $\mathbf{B a}$ & $\begin{array}{l}\text { WT } \\
\end{array}$ & $\overline{Q S}$ & LPR & PFE \\
\hline 1 & Jo & 0 & 0.5 & 0.5 & 0.5 & 0 & 0 & 0 & 0 & 0 & 0.5 & 0 & 0 & 0 & 0 \\
\hline 2 & $\mathrm{Re}$ & 0.5 & 0 & 0.5 & 0 & 0 & 0 & 0 & 0 & 0 & 0.5 & 0 & 0 & 0 & 0 \\
\hline 3 & HNSS & 0.7 & 0.5 & 0 & 0.5 & 0 & 0 & 0 & 0 & 0 & 0.5 & 0 & 0 & 0 & 0 \\
\hline 4 & LNSS & 0.5 & 0.5 & 0.5 & 0 & 0 & 0 & 0 & 0 & 0 & 0.6 & 0 & 0 & 0 & 0 \\
\hline 5 & TTSP & 0.5 & 0.5 & 0.5 & 0.5 & 0 & 0 & 0 & 0 & 0 & 0.5 & 0 & 0 & 0 & 0 \\
\hline 6 & IoC & 0.6 & 0.6 & 0.6 & 0.6 & 0.5 & 0 & 0 & 0 & 0 & 0.5 & 0 & 0 & 0 & 0 \\
\hline 7 & TE & 1 & 1 & 1 & 1 & 1 & 1 & 0 & 0 & 0 & 1 & 1 & 1 & 1 & 1 \\
\hline 8 & WF & 1 & 1 & 1 & 1 & 1 & 1 & 1 & 0 & 0 & 1 & 1 & 1 & 1 & 1 \\
\hline 9 & S-oSF & 1 & 1 & 1 & 1 & 1 & 1 & 1 & 1 & 0 & 1 & 1 & 1 & 1 & 1 \\
\hline 10 & $\mathrm{Ba}$ & 0 & 0 & 0 & 0 & 0 & 0 & 0 & 0 & 0 & 0 & 0 & 0 & 0 & 0 \\
\hline 11 & WT & 1 & 1 & 1 & 1 & 1 & 1 & 0 & 0 & 0 & 1 & 0 & 1 & 1 & 1 \\
\hline 12 & QS & 1 & 1 & 1 & 1 & 1 & 1 & 0 & 0 & 0 & 1 & 0 & 0 & 1 & 1 \\
\hline 13 & LPR & 1 & 1 & 1 & 1 & 1 & 1 & 1 & 1 & 0 & 1 & 1 & 1 & 0 & 1 \\
\hline 14 & PFE & 1 & 1 & 1 & 1 & 1 & 1 & 1 & 1 & 0 & 1 & 1 & 1 & 1 & 0 \\
\hline
\end{tabular}

Fig 6. Fuzzy Direct Reachability Matrix

\section{LIMITATIONS AND FUTURE SCOPE}

Further Structural Equation Modelling (SEM), Multi Criteria Decision Making (MCDM) techniques like ANP and AHP also been used for causal relation among the enablers .

\section{ACKNOWLEDGMENTS}

Our thanks to the anonymous reviewers whose comments have helped us in improving the manuscript . Co-author Remica Aggarwal also pay her sincere regards to Prof. S.P Singh of DMS , IIT Delhi for disseminating the knowledge about ISM methodology.

\section{REFERENCES}

[1] Murthy, M.S.R , Pushpha Lata, M. 2014. Minimizing the Waiting Time at Bank ATM for Service with Queuing Model Research Paper, 3(1)

[2] Sheikh, T., Singh, S.K. , Kashyap, A.K. 2013. Application of Queuing theory for the Improvement of Bank Service International Journal of Advanced Computational Engineering and Networking, ISSN: 2320-2106. 1(4)

[3] Bajpai, P. and Maneesha . 2013. Measure of Performance of Queuing Models and Behavior of Customers in Real Life Applications International Journal of Applied Physics and Mathematics, 3(5).

[4] Chowdhury, M.S.R, Rahman , M.T. and Kabir, M.R. 2013. Solving of Waiting Lines Models in the Bank Using Queuing Theory Model the Practice Case: Islami
Bank Bangladesh Limited, Chawkbazar Branch, Chittagong IOSR Journal of Business and Management (IOSR-JBM) , 10(1), 22-29.

[5] S. A. AL-Jumail . 2011. Automatic Queuing Model for Banking Application(IJACSA) International Journal of Advanced Computer Science and Applications. 2(7).

[6] Hao, T., Yifei , T. 2011. Study on Queuing System Optimization of Bank Based on BPR 2011 3rd International Conference on Environmental Science and Information Application Technology (ESIAT 2011).

[7] Chandraker, R. and Kumar, R. 2013. Analysis of practices for implementation of GSCM in Chhattisgarh Manufacturing Industries (India) using ISM technique, International Journal of Industrial Engineering \& Technology (IJIET), 3 (3), 35-44.

[8] Chandraker, R. and Bais, M.S. 2013. Modelling of the factors influencing the phenomenon of bullwhip effect in the seasonal products using ISM technique. Elixir Marketing Mgmt. 62, pp. 17748-17752.

[9] Verma, S. Sridhar. K, Chandraker, R. 2015. Barriers Analysis of Bank Queuing System using ISM and MicMac Approach, International journal of engineering research and technology (IJERT) ISNCESR , 3(20).

[10] Warfield, J. N. 1974. Developing interconnection matrices in structural modeling. IEEE Transactions on System, Man, and Cybernetics, SMC-4 (1), 81-87. 
[11] Alex, M.K. 2019. Modeling and Analysis of Queuing Systems in Banks: (A Case Study of Banque Commerciale du Congo-BCDC/Mbujimayi), Université Officielle de Mbujimayi, https://mpra.ub.unimuenchen.de/92579/MPRA Paper No. 92579.

[12] Christopher M. P. A. \& D., D. (1997). Bringing Quality, Customer service and Marketing together. Relationship Marketing. Batter Worth: Heinemann.

[13] F.A, M. 2014. Appliquer le ToC Lean Six Sigma dans les services: Déployer et metre en oeuvre les méthodes et outils d'une relation de service performante et durable. Paris: Lexitis éditions.

[14] Farayibi, A. 2016. Investigating the Application of Queue Theory in the Nigerian Banking System. Munich Personal RePEC Archive , 1-14.

[15] Grace, W. K. 2012. Waiting lines management and customer satisfaction in commercial banks in Kenya. University of Naîrobie .
[16] Yusuf, M. O., Blessing, N. \& Kazeem, A. O. 2015. Queuing Theory and Customer Satisfaction : A Review of Performance, Trends and Application in Banking Practice (A Study of First Plc Gwagwalada, Abuja Branch). European Journal of Business and Management, 7(35), pp. 90-96.

[17] Katz, K. L., Larson, B. M. and Larson , R. C. 1991. Prescriptions for the Waiting in-Line Blues : Entertain, Enlighten and Engage. Sloan Management Review, $32(2)$.

[18] Taylor, S. 1995. The effects of filled waiting time and service provider control over the delay on evaluations of service. Journal of Academic Marketing Science, 23(2), 38-48.

[19] Kendall, 1953. Classification of Queuing model..people.revoledu.com/kardi/tutorial/Queuing/Kend all- Notation.html. 